\title{
DELIMITACJA ZADAŃ I KOMPETENCJI RADY MINISTRÓW I PREZYDENTA RP ORAZ ICH WSPÓŁDZIAŁANIE W ZAKRESIE WEWNĘTRZNEGO I ZEWNĘTRZNEGO BEZPIECZEŃSTWA PAŃSTWA I PORZĄDKU PUBLICZNEGO
}

Prezydent Rzeczypospolitej Polskiej, wraz z Radą Ministrów, na mocy art. 10 Konstytucji $\mathrm{RP}^{1}$ stanowią władzę wykonawczą w Rzeczypospolitej Polskiej. Z tego tytułu obu organom przysługuje szereg kompetencji w zakresie bezpieczeństwa wewnętrznego i zewnętrznego państwa oraz porządku publicznego. W związku ze wspomnianym dualizmem, w niniejszej publikacji pokrótce przedstawione zostaną instrumentalne formy współpracy egzekutywy, jej kompetencje w dziedzinie obronności i bezpieczeństwa, a także zostanie nakreślony zakres uzupełniania się i przenikania kompetencji Prezydenta i Rady Ministrów w tym zakresie.

Analiza postanowień Konstytucji w zakresie uprawnień organów władzy wykonawczej w Polsce prowadzi do wniosku, że Polska nie przyjęła ani rozwiązania stosowanego w Stanach Zjednoczonych Ameryki Północnej i Francji, w którym to rolę dominującą $\mathrm{w}$ omawianym zakresie sprawuje prezydent, ani rozwiązania znanego m.in. z Niemiec i Wielkiej Brytanii, gdzie za bezpieczeństwo i obronność państwa pełną odpowiedzialność ponosi szef rządu wraz z gabinetem. W Polsce zdecydowano się bowiem na system mieszany, w którym Rada Ministrów z Prezydentem wzajemnie się uzupełniają, $z$ jednej strony nawzajem inicjując i wykonując pewne działania zmierzające do realizacji nałożonych na nie obowiązków w zakresie bezpieczeństwa i obronności państwa, a z drugiej spełniając względem siebie rolę kontrolno-nadzorczą ${ }^{2}$.

Istotę relacji obu organów władzy wykonawczej trafnie podsumowuje D. Dudek twierdząc, że pomiędzy Prezydentem RP i Radą Ministrów zachodzą silne, aczkolwiek niesymetryczne związki o charakterze funkcjonalnym, organizacyjnymi kompetencyjnym. Związki te $\mathrm{z}$ jednej strony mają potencjał do stworzenia najwięk-

\footnotetext{
Konstytucja Rzeczypospolitej Polskiej z dnia 2 kwietnia 1997 r. (Dz.U. z 1997 r. Nr 78, poz. 483 ze zm.).

M. Surmański, Bezpieczeństwo i obronność państwa w świetle kompetencji prezydenta RP i Rady Ministrów, „Bezpieczeństwo Narodowe” 2013, nr 1 (25), s. 136-137.
} 
szego pola do współdziałania między władzami w RP, a z drugiej mogą być przyczyną niezwykle silnych, instytucjonalnych konfliktów³

Podstawą do wszczęcia rozważań o delimitacji zadań Prezydenta i Rady Ministrów w zakresie bezpieczeństwa wewnętrznego i zewnętrznego państwa i porządku publicznego powinny być przepisy Konstytucji. Przede wszystkim, w art. 144 ust. 3, który zawiera prerogatywy Prezydenta próżno szukać uprawnień do podejmowania samodzielnych działań i decyzji w zakresie bezpieczeństwa i obronności z wyłączeniem inicjatywy ustawodawczej (która summa summarum, przy braku poparcia Parlamentu do niczego nie prowadzi). Należy zatem rozważyć relację przepisów Konstytucji, tj. art. 146 ust. 4 pkt 7, 8 i 11, na mocy których Rada Ministrów zapewnia bezpieczeństwo wewnętrzne i zewnętrzne państwa oraz porządek publiczny a także sprawuje ogólne kierownictwo w dziedzinie obronności kraju, do art. 126 ust. 2, który stanowi, iż Prezydent stoi na straży suwerenności i bezpieczeństwa państwa oraz nienaruszalności i niepodzielności jego terytorium. W opinii B. Opalińskiego, przepisy te mają charakter komplementarny, w konsekwencji czego Prezydent nie został wyposażony w kompetencje umożliwiające podejmowanie działań prewencyjnych lub stabilizujących, a w każdym przypadku zagrożenia bezpieczeństwa Rzeczypospolitej zmuszony jest on do nakłaniania Rady Ministrów do podjęcia odpowiednich działań ${ }^{4}$.

\section{Formy współpracy instytucjonalnej}

Szczególnym środkiem wpływu Prezydenta na Radę Ministrów jest bez wątpienia powołanie Rady Gabinetowej. Instytucja ta została zdefiniowana w art. 141 Konstytucji. Zgodnie z ww. przepisem, Rada Gabinetowa zwoływana jest przez Prezydenta w „sprawach szczególnej wagi”. Radę Gabinetową tworzy Rada Ministrów obradująca pod przewodnictwem Prezydenta, należy jednak podkreślić, iż Radzie Gabinetowej nie przysługują kompetencje i uprawnienia Rady Ministrów. Rada Gabinetowa jest więc forum do wymiany poglądów i podjęcia debaty w sprawach szczególnie istotnych przez Prezydenta i Radę Ministrów bez ingerencji w kompetencje sektora rządowego. Z jednej strony więc Rada Gabinetowa daje możliwość Prezydentowi wyrażenia swojego poglądu na kluczowe problemy dotyczące obronności państwa, a z drugiej jest ona doskonałą sposobnością do realizacji przez Radę Ministrów swojej roli doradczej względem głowy państwa ${ }^{5}$.

Osobne słowo w zakresie instytucjonalnego współdziałania Prezydenta i Rady Ministrów w sektorze wewnętrznego i zewnętrznego bezpieczeństwa państwa należy się także Radzie Bezpieczeństwa Narodowego. Rada Bezpieczeństwa Narodo-

D. Dudek, Autorytet Prezydenta a konstytucja Rzeczypospolitej Polskiej, Lublin 2013, s. 88.

B. Opaliński, Rozdzielenie kompetencji władzy wykonawczej między Prezydenta RP oraz Radę Ministrów na tle Konstytucji Rzeczypospolitej Polskiej z 1997 r., Warszawa 2002, s. 168-170.

5

W. Skrzydło, Konstytucja Rzeczypospolitej Polskiej. Komentarz, Warszawa 2013 r., s. 179-180. 
wego jest konstytucyjnym (art. 135 Konstytucji) organem doradczym Prezydenta w zakresie wewnętrznego i zewnętrznego bezpieczeństwa państwa. Do zadań Rady Bezpieczeństwa Narodowego należy przede wszystkim ,rozpatrywanie kwestii i wyrażanie opinii dotyczących bezpieczeństwa państwa, w tym m.in.:

- generalnych założeń bezpieczeństwa państwa,

- założeń i kierunków polityki zagranicznej,

- kierunków rozwoju Sił Zbrojnych,

- problemów bezpieczeństwa zewnętrznego,

- zagrożeń bezpieczeństwa wewnętrznego i środków ich przeciwdziałania."

Rada Bezpieczeństwa Narodowego zwoływana jest przez Prezydenta, jednak zgodnie z przyjętym zwyczajem, w skład Rady Bezpieczeństwa Międzynarodowego wchodzą m.in. Prezes Rady Ministrów, Minister Obrony Narodowej, Minister Spraw Zagranicznych i Minister Spraw Wewnętrznych.

Jako iż Rada Bezpieczeństwa Narodowego ma charakter stricte doradczy ${ }^{7}$, nie sposób wyrokować o jej realnym wpływie na współpracę Prezydenta z Radą Ministrów w zakresie bezpieczeństwa wewnętrznego i zewnętrznego państwa oraz porządku publicznego. Jednakże, ze względu na konstytucyjne usytuowanie Rady Bezpieczeństwa Narodowego uznać należy, że wolą ustawodawcy było utworzenie instytucji koordynującej działania Prezydenta i Rady Ministrów w obszarze bezpieczeństwa i obronności państwa ${ }^{8}$. W przyjętym w Rzeczypospolitej rozwiązaniu ustrojowym, zakładającym mieszany system sprawowania władzy w omawianym zakresie stwierdzić należy, iż Rada Bezpieczeństwa Narodowego stanowi istotny element uzgadniania stanowisk rządu i Prezydenta w celu prowadzenia jednolitej polityki bezpieczeństwa i obronności.

\section{Stany nadzwyczajne}

Dobrym przykładem rozdzielenia kompetencji Prezydenta i Rady Ministrów w zakresie bezpieczeństwa wewnętrznego i zewnętrznego państwa i porządku publicznego jest delimitacja uprawnień i wymóg współpracy ww. organów w czasie stanów nadzwyczajnych, czego dowodzi np. procedura wprowadzenia stanu wojennego, co czyni Prezydent na wniosek Rady Ministrów ${ }^{9}$. Niniejsze prowadzi do prostego wniosku, że niemożliwe jest podjęcie kluczowej z punktu widzenia funkcjonowania, a być może nawet i bytu państwa, decyzji wyłącznie przez Prezydenta

6 https://www.bbn.gov.pl/pl/prezydenta-rp/rada-bezpieczenstwa-nar/rola-rbn/6000,Rada-Bezpieczenstwa-Narodowego.html (data dostępu: 29.09.2015 r.).

7 W. Odrowąż-Sypniewski, Opinia w sprawie udziału Marszałka Sejmu w Radzie Bezpieczeństwa Narodowego, „Przegląd Sejmowy” 1998, nr 3, s. 78.

8 T. Słomka, Prezydent Rzeczypospolitej po 1989 roku. Ujęcie porównawcze, Warszawa 2005, s. 160-161.

9 A. Chorążewska, Model prezydentury w praktyce politycznej po wejściu w życie Konstytucji RP z 1997 r., Warszawa 2008, s. 105. 
lub wyłącznie przez Radę Ministrów. Wobec powyższego, współpraca Prezydenta i Rady Ministrów w zakresie stanów wyjątkowych dość trafnie obrazuje zasady rządzące przedmiotową współpracą.

Szczegółowo zasady współdziałania egzekutywy w czasie trwania stanu wojennego regulują przepisy ustawy o stanie wojennym ${ }^{10}$, zgodnie $\mathrm{z}$ którą , $\mathrm{W}$ czasie stanu wojennego organy władzy publicznej działają w dotychczasowych strukturach organizacyjnych państwa i w ramach przysługujących im kompetencji, z zastrzeżeniem przepisów niniejszej ustawy". Kluczowy, z punktu widzenia analizowanej materii jest art. 10 ust. 2 ustawy o stanie wojennym. Zgodnie z nim, Prezydent RP w czasie stanu wojennego, na wniosek Rady Ministrów:

- postanawia o przejściu organów władzy publicznej na określone stanowiska kierowania,

- postanawia o stanach gotowości bojowej Sił Zbrojnych Rzeczypospolitej Polskiej, zwanych dalej „Siłami Zbrojnymi”,

- określa zadania Sił Zbrojnych w czasie stanu wojennego,

- może mianować Naczelnego Dowódcę Sił Zbrojnych.

Częściowo analogiczne rozwiązania zostały przyjęte w ustawie o stanie wyjątkowym ${ }^{11}$, który wprowadza Prezydent na wniosek Rady Ministrów (art. 3 ustawy), a także na jej wniosek postanawia o wydłużeniu lub skróceniu czasu, na jaki wprowadzono stan wyjątkowy (art. 5). Istotną jednak, w kontekście omawianej współpracy organów egzekutywy, instytucję zawiera art. 10, na mocy którego Prezes Rady Ministrów został zobligowany do bieżącego informowania Prezydenta o skutkach wprowadzenia stanu wyjątkowego, a także o rodzaju i skutkach działań podejmowanych w celu przywrócenia normalnego funkcjonowania państwa. Finalnie, na mocy art. 11 ust. 1 ustawy o stanie wyjątkowym, Prezydent RP - na wniosek Prezesa Rady Ministrów - może postanowić o użyciu oddziałów i pododdziałów Sił Zbrojnych Rzeczypospolitej Polskiej do przywrócenia normalnego funkcjonowania państwa, jeżeli dotychczas zastosowane siły i środki zostały wyczerpane.

Między innymi na podstawie powyższego stwierdzić należy, że całokształt przepisów zakładających współpracę Prezydenta i Rady Ministrów w dziedzinie obronnościi bezpieczeństwa ma charakter wymuszający kooperację organów stanowiących władzę wykonawczą, co wynika ze specyfiki regulowanej materii ${ }^{12}$ i jest wyrazem demokratycznej idei cywilnej kontroli nad siłami zbrojnymi ${ }^{13}$.

\footnotetext{
10 Ustawa z dnia 29 sierpnia 2002 r. o stanie wojennym oraz o kompetencjach Naczelnego Dowódcy Sił Zbrojnych i zasadach jego podległości konstytucyjnym organom Rzeczypospolitej Polskiej (tekst jedn.: Dz.U. z 2014 r. poz. 1815 z późn. zm.).

11 Ustawa z dnia 21 czerwca 2002 r. o stanie wyjątkowym (tekst jedn.: Dz.U. z 2014 r., poz. 1191).

12 M. Surmański: Bezpieczeństwo i obronność państwa..., op. cit., s. 136-137.

13 O demokratycznej kontroli nad armią we współczesnym świecie zob.: W. Wołpiuk, Siły zbrojne w regulacjach konstytucyjnych, Warszawa 1998.
} 


\section{Zwierzchnictwo nad Siłami Zbrojnymi i kompetencje ustawowe}

Finalnie, osobnej analizy wymaga bodaj najistotniejszy, z punktu widzenia uprawnień Prezydenta Rzeczypospolitej Polskiej, konstytucyjny przepis kompetencyjny w zakresie zapewnienia bezpieczeństwa i obronności państwa. Mowa tu rzecz jasna o art. 134 ust. 2 Konstytucji, zgodnie z którym Prezydent jest najwyższym zwierzchnikiem Sił Zbrojnych. Jednakże już ust. 2 przywołanego przepisu stanowi, że w czasie pokoju zwierzchnictwo Prezydenta nad Siłami Zbrojnymi wykonywane jest za pośrednictwem Ministra Obrony Narodowej. Zwierzchnictwo nad Siłami Zbrojnymi w czasie pokoju sprowadza się głównie do funkcji mianowania członków Sił Zbrojnych, tj. Szefa Sztabu Generalnego i dowódców rodzajów Sił Zbrojnych (Wojska Lądowe, Siły Powietrzne, Marynarka Wojenna i Siły Specjalne ${ }^{14}$ ) oraz uprawnień w zakresie przyznawania orderów i odznaczeń ${ }^{15}$.

Postanowienia w zakresie mianowania ww. członków Sił Zbrojnych, co prawda, nie wymagają formalnego wniosku, jednak w praktyce nominacje te poprzedzane są konsultacjami z Ministrem Obrony Narodowej i Prezesem Rady Ministrów ${ }^{16}$. Istotnym jest, że w czasie wojny Minister Obrony Narodowej zostaje skierowany na nieco boczny tor, ponieważ zwierzchnictwo Prezydenta nad Siłami Zbrojnymi dokonuje się za pośrednictwem Naczelnego Dowódcy Sił Zbrojnych (art. 134 ust. 4 Konstytucji), który jednakże jest mianowany przez Prezydenta na wniosek Prezesa Rady Ministrów.

Ponadto, jako przykłady szczególnej współpracy Prezydenta Rzeczypospolitej Polskiej i Rady Ministrów w zakresie bezpieczeństwa i obronności państwa na poziomie kompetencji ustawowych należy wskazać między innymi zatwierdzanie przez Prezydenta, na wniosek Prezesa Rady Ministrów, strategii bezpieczeństwa narodowego ${ }^{17}$, wydawanie przez Prezydenta, na wniosek Prezesa Rady Ministrów, Polityczno-Strategicznej Dyrektywy Obronnej Rzeczypospolitej Polskiej oraz innych dokumentów wykonawczych do strategii bezpieczeństwa narodowego ${ }^{18}$, decydowanie przez Prezydenta, na wniosek Rady Ministrów lub Prezesa Rady Ministrów o użyciu jednostek wojskowych poza granicami państwa ${ }^{19}$ oraz decydowanie przez

\footnotetext{
14 Por.: art. 3 ust. 3 ustawy z dnia 21 listopada 1967 r. o powszechnym obowiązku obrony Rzeczypospolitej Polskiej (tekst jedn.: Dz.U. z 2015 r., poz. 827).

15 Szczegółowo o trybie nadawania orderów i odznaczeń oraz ich rodzajach zob.: B. Banaszak, Kompetencje Prezydenta Rzeczypospolitej Polskiej dotyczące orderów i odznaczeń, „Przegląd Sejmowy” 2002, nr 4, s. 27-39.

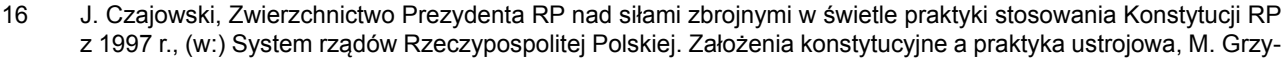
bowski (red.), Warszawa 2006, s. 66 i n.

17 Art. 4a ust. 1 pkt 1 ustawy z dnia 21 listopada 1967 r. o powszechnym obowiązku obrony...

18 Art. 4a ust. 1 pkt 2 ustawy z dnia 21 listopada 1967 r. o powszechnym obowiązku obrony...

19 Art. 3 ust. 1 ustawy z dnia 17 grudnia 1998 r. o zasadach użycia lub pobytu Sił Zbrojnych Rzeczypospolitej Polskiej poza granicami państwa (tekst jedn.: Dz.U. z 2014 r., poz. 1510).
} 
Prezydenta, na wniosek Prezesa Rady Ministrów o użyciu oddziałów lub pododdziałów Sił Zbrojnych w czasie stanu wyjątkowego ${ }^{20}$.

Podobne dowody koniecznej kooperacji pomiędzy Prezydentem a Radą Ministrów w zakresie bezpieczeństwa i obronności państwa można mnożyć analizując kolejne ustawy regulujące materię bezpieczeństwa narodowego. Istotny jest jednak wykazany wyżej mechanizm udowadniający, iż w obliczu funkcjonowania konstytucyjnych organów państwa podejmowanie decyzji w przedmiocie bezpieczeństwa i obronności państwa, jego suwerenności i porządku publicznego, spoczywa łącznie na obu organach władzy wykonawczej Rzeczypospolitej ${ }^{21}$.

Trafnie konstytucyjne usytuowanie organów egzekutywy w zakresie bezpieczeństwa i obronności podsumował Trybunał Konstytucyjny w wyroku z dnia 27 czerwca 2008 r. ${ }^{22}$, w którym stwierdził, że „W myśl art. 5 Konstytucji Rzeczpospolita Polska strzeże niepodległości i nienaruszalności swojego terytorium. Przepis ten określa ogólne zadania państwa, które powinny być realizowane przez wszystkie organy władzy publicznej i instytucje publiczne, o ile pozwalają im na to przyznane im kompetencje. Do konstytucyjnych zadań Prezydenta należy stanie na straży suwerenności i bezpieczeństwa państwa oraz nienaruszalności i niepodzielności jego terytorium (art. 126 ust. 2 Konstytucji). Do Rady Ministrów należy zapewnianie bezpieczeństwa zewnętrznego państwa (art. 146 ust. 4 pkt 8 Konstytucji). Analiza przepisów konstytucyjnych prowadzi do wniosku, że zadania różnych organów mogą nakładać się na siebie. Ochrona niepodległości państwa i niepodzielności jego terytorium oraz zapewnienie bezpieczeństwa i nienaruszalności jego granic jest konstytucyjnym zadaniem Prezydenta RP, Rady Ministrów oraz wszelkich innych organów władzy publicznej.”. W rezultacie powyższego założenia, akty prawne wyposażające Prezydenta w konkretne kompetencje w dziedzinie obronności i bezpieczeństwa uzależniają podjęcie działań przez głowę państwa od zgody lub wniosku członka Rady Ministrów.

\section{Podsumowanie}

Słowem podsumowania podnieść należy, iż polski ustrojodawca, być może ze względu na doświadczenia historyczne, zdecydował się powierzyć ogół kompetencji w zakresie bezpieczeństwa wewnętrznego i zewnętrznego państwa i porządku publicznego obu konstytucyjnym organom władzy wykonawczej. Na gruncie analizowanych przepisów zarówno Konstytucji, jak i ustaw zarysowuje się wyraźny model współdziałania Rady Ministrów i Prezydenta Rzeczypospolitej Polskiej w wykonywaniu zadań z zakresu bezpieczeństwa i obronności. Owszem, ze względu Marynarki Wojennej" nr 4 (187)/2011, Gdynia 2011, s. 325-335. 
na unormowania konstytucyjne przyjąć należy, że pierwszoplanową rolę w niniejszej współpracy sprawuje Rada Ministrów, jednakże w kluczowych sprawach dla funkcjonowania i bytu państwa niezbędna jest jej kooperacja z Prezydentem.

Co do charakteru przyjętych rozwiązań trzeba je sklasyfikować jako emanację współczesnego modelu ustroju parlamentarno-gabinetowego w państwie demokratycznym, a w szczególności obowiązującej zasady cywilnej kontroli nad armiąą. Oznacza to, że Rada Ministrów wraz z Prezydentem nawzajem uniemożliwiają sobie wykorzystanie armii w niezbędnym zakresie. Niniejsze organy nie są w stanie podjąć strategicznych działań bez aprobaty drugiego z nich. Przyjęte unormowania mają swoje zalety w postaci ograniczenia wpływu wybranego organu na kluczowy z punktu widzenia państwa obszar, jakim jest bezpieczeństwo i obronność, jednakże wydaje się, że specyfika działań w zakresie obronności wymaga innych rozwiązań. W opinii autora funkcjonujące w polskim prawodawstwie rozwiązania uniemożliwiają podjęcie skutecznych działań w dziedzinie bezpieczeństwa i obronności. Mechanizmy gwarantujące, że ani Rada Ministrów, ani Prezydent nie uzyskają zbyt dużych wpływów w kształtowaniu właściwości obronnych państwa powodują znaczące spowolnienie podejmowania działań istotnych z punktu widzenia potencjalnych działań prewencyjnych lub wojennych. $Z$ tego powodu, w opinii autora zasadnym jest przyjęcie ustawowych rozwiązań gwarantujących Radzie Ministrów większy wpływ na politykę bezpieczeństwa i obronności szczególnie w zakresie bezpośredniego zagrożenia bezpieczeństwa państwa lub porządku publicznego.

\section{BIBLIOGRAFIA}

Ryszard Balicki. 2014. „Zwierzchnictwo prezydenta RP nad Siłami Zbrojnymi (wybrane problemy)”. Przegląd Prawa Konstytucyjnego 2 (18): 13-25.

Bogusław Banaszak. 2002. „Kompetencje Prezydenta Rzeczypospolitej Polskiej Dotyczące orderów i odznaczeń”. Przegląd Sejmowy 4 (510): 27-39.

Anna Chorążewska. 2008. Model prezydentury w praktyce politycznej po wejściu w życie Konstytucji RP z 1997 r. Warszawa: Wydawnictwo Sejmowe.

Jacek Czajowski. 2006. Zwierzchnictwo Prezydenta RP nad siłami zbrojnymi w świetle praktyki stosowania Konstytucji RP z 1997 r. W System rządów Rzeczypospolitej Polskiej. Założenia konstytucyjne a praktyka ustrojowa, 66-78. Warszawa: Wydawnictwo Sejmowe.

Dariusz Dudek. 2013. Autorytet Prezydenta a Konstytucja Rzeczypospolitej Polskiej. Lublin: Wydawnictwo Katolickiego Uniwersytetu Lubelskiego.

Wojciech Odrowąż-Sypniewski. 1998. „Opinia w sprawie udziału Marszałka Sejmu w Radzie Bezpieczeństwa Narodowego". Przegląd Sejmowy 3 (26): 78-80. 
Bartłomiej Opaliński. 2002. Rozdzielenie kompetencji władzy wykonawczej między Prezydenta RP oraz Radę Ministrów na tle Konstytucji Rzeczypospolitej Polskiej z 1997 r. Warszawa: Wolters Kluwer S.A.

T. Słomka. 2004. Prezydent Rzeczypospolitej po 1989 roku. Ujęcie porównawcze. Warszawa: Oficyna Wydawnicza ASPRA-JR.

Marek Surmański. 2013. „Bezpieczeństwo i obronność państwa w świetle kompetencji prezydenta RP i Rady Ministrów”. Bezpieczeństwo narodowe 1 (25): 125-139.

Wiesław Skrzydło. 2013. Konstytucja Rzeczypospolitej Polskiej. Komentarz. Warszawa: Wolters Kluwer S.A.

Mariusz Wojciszko. 2011. „Kompetencje naczelnych organów państwa w dziedzinie obronności”. Zeszyty naukowe Akademii Marynarki Wojennej 4 (187): 323-341.

Waldemar Wołpiuk. 1998. Siły zbrojne w regulacjach konstytucyjnych. Warszawa: Wydawnictwo SCHOLAR. 


\section{SEPARATION OF DUTIES AND COMPETENCIES AND COOPERATION BETWEEN THE COUNCIL OF MINISTERS AND THE PRESIDENT OF POLAND IN THE AREA OF INTERNAL AND EXTERNAL SECURITY OF THE STATE AND PUBLIC ORDER}

The present publication describes the problem of separation of duties and competencies between the Council of Ministers and the president of Poland, in the area of internal and external security of the state and public order and their necessary cooperation in this respect. Further the article addresses the field of cooperation between the various bodies of public authority in the area of national security and defense. It also contains an attempt todefine and assess Poland's model of cooperation of public authorities in the face of threat to state sovereignty, accepted under its constitution.

Keywords: national security, national defence, Council of Ministers, president of Poland, competencies

Słowa kluczowe: bezpieczeństwo, obronność, Rada Ministrów, Prezydent RP, kompetencje 